\title{
Study on the Cultivation of International Talents of Hotel Management in Higher Vocational Colleges Against the Background of Globalization
}

\author{
Huaqing Song \\ Dalian Vocational and Technical College \\ Dalian, China
}

\begin{abstract}
In the context of tourism globalization, high-end hotels in different countries are developing rapidly At the same time, there is a shortage of international hotel professionals. How to effectively tackle this problem, it is necessary to strengthen the training of international hotel management professionals to ensure that there are enough relevant professionals to fill the vacancy in the society. This paper analyzes the relationship between tourism globalization and international hotel talents, and brings forward some effective measures to improve the quality of training hotel management professionals in higher vocational colleges.
\end{abstract}

Keywords-tourism globalization; higher vocational education; hotel management specialty; training of international talents

\section{INTRODUCTION}

Since the 21 st century, tourism has developed fast and tourism globalization has been quite common. Enhancing the development of tourism in various countries is of great significance to the improvement of comprehensive national strength and the growth of national economy. However, under the background of tourism globalization, there is a shortage of international talents of hotel management specialty in higher vocational colleges. Training such comprehensive talents has become an urgent problem to be solved. This paper discusses and analyzes this problem in the hope of effectively upgrading the quality of personnel training and providing information for China's hotel management specialty.

\section{TOURISM GLOBALIZATION AND INTERNATIONAL HOTEL TALENTS}

Tourism globalization refers to the integration of tourism in various countries and regions in the world, and it is also the inevitable result of the rapid development of tourism. The globalization of tourism has several distinct features. First, the proportion of tourism in the national economy of various countries around the world is increasing. Second, the rapid development of tourism has effectively enhanced comprehensive national strength of various countries around the world. If a country's tourism industry develops, an international hotel is indispensable. The normal operation of the hotel needs international hotel management professionals, but a large number of such talents are scarce in the world. So there are many problems in their training. Due to the shortage of such talents, the training of hotel management talents is required. The quality of professionals is not good enough to manage a hotel, which largely affects the development of national tourism, as well as rapid development and growth of comprehensive national strength and national economy to a certain extent. Therefore, the globalization of tourism is closely related to international hotel management professionals. Under the background of tourism globalization, it is urgent to intensify the training of international hotel management professionals.

\section{The Current Situation of Training of Hotel MANAGEMENT PROFESSIONALS IN CHINA'S HigheR VOCATIONAL COLLEGES}

Most of China's higher vocational colleges have trained a large number of excellent hotel management professionals, which largely advances the rapid development of China's tourism industry. Therefore, China has obvious advantages in the training of hotel management professionals in higher vocational colleges. China has opened the hotel management specialty for many years, and education in this specialty is relatively mature. Besides, many international hotels have carried out cooperation with higher vocational colleges, enabling students to have a better understanding of future jobs in college, effectively improving professionals' working ability. On the whole, there are two characteristics in the training of hotel management professionals in China's higher vocational colleges: first, they adopt the "school-enterprise cooperation" to effectively improve students' practical ability and make them adapt to the job after graduation earlier. Second, higher vocational colleges have a strong teaching function in the training of hotel management professionals, with practical learning objectives and teaching content. It can be seen that China's higher vocational colleges are leading the world in the cultivation of hotel management professionals. However, now higher vocational colleges have encountered many problems in the training of hotel management professionals. At the same time, they also have many limitations in the training of hotel management professionals. These problems greatly affect the rapid 
development of China's tourism industry and lead to an unstable growth of the national economy.

\section{LIMITATIONS IN THE TRAINING OF HOTEL}

MANAGEMENT PROFESSIONALS IN HighER VOCATIONAL COLLEGES AGAINST THE BACKGROUND OF TOURISM GLOBALIZATION

Despite the fact that China has made remarkable achievements in professional hotel management in decades of practice and exploration, the development trend of hotel internationalization and collectivization makes greater demands on talents in the context of tourism globalization. This is both an opportunity and a challenge for tourism vocational education. At present, the hotel management specialty in China's higher vocational colleges has played a crucial role in the development of localized hotel and lowend service and management talents. However, facing new opportunities and challenges, talent training still shows some limitations.

\section{PRACTICE AND EXPLORATION ON THE TRAINING OF INTERNATIONAL TALENTS OF HOTEL MANAGEMENT SPECIALTY IN CHINA'S HighER VocATIONAL COLLEGES}

\section{A. Establishing an International Curriculum System and Teaching Content}

Colleges can attain the goal of talent training through teaching. Curriculum systems, teaching content and teaching methods all embody teaching quality and the effectiveness of international education. For this reason, to cultivate international talents, it is necessary to establish a curriculum system and teaching content in conformity with international standards.

\section{B. Cooperation Between Chinese and Foreign Colleges to Establish International Practice and Employment Bases}

In recent years, China's tourism vocational colleges have achieved good results in practice base construction through college-enterprise cooperation model. Many colleges have built long-term cooperative relations with domestic transnational hotel groups to provide a good platform for students' professional practice and employment.

\section{Building a High-quality International Teaching Staff Team}

Building a high-quality and comprehensive international teaching team is the key to training international hotel talents. It is also a basic guarantee to adapt to the tourism globalization, upgrade education quality and deepen the reform of teaching. First of all, colleges should regularly invite managers of domestic and foreign cooperative hotel groups to give special lectures to students or guide comprehensive teaching. Second, colleges directly introduce professional English teachers from transnational companies to ensure bilingual education. Besides, colleges also recruit foreign teachers and ambassadors directly from the United States, the United Kingdom, Japan and South Korea. Teaching ideas and methods conform to international standards. Teachers can also improve their consulting skills through visits, overseas career training and international college exchanges.

\section{CARRYING FORWARD THE IDEA OF COLLEGE RUNNING BASED ON EDUCATION AND ESTABLISHING THE IDEA OF INTERNATIONAL SCHOOL RUNNING}

With the deepening of economic globalization, it is a prerequisite and advanced consciousness to establish the concept and idea of higher vocational education internationalization. However, the trend of internationalization of China's higher vocational education has just begun and is still a new thing. Many people are not familiar with it and have no sense of internationalization. In the process of cooperation with international hotel education institutions, colleges have transformed their learning modes from simple imitation to learning and innovation, cultivated high-quality and skilled talents with international vision, fluent foreign language application ability and cross-cultural communication ability, so that students can master international hotel management knowledge and gradually clear operation rules. The organic combination of international core curriculum textbooks and local characteristic curriculum textbooks constitutes the new curriculum standard textbook system. If possible, colleges can make use of the international marketing concept of overseas educational institutions and recruit students from overseas markets, so as to achieve a mixed curriculum and an effective English teaching environment for Chinese and foreign students. Especially, the carrier has played a vital role in cultivating students' foreign language application ability and cross-cultural communication ability. China's higher vocational colleges must have the advanced concept of international vocational education, improve the teaching management level to the international standard, and constantly heighten their awareness of international competitiveness of higher vocational education, so that the internationalization level of higher vocational education has been continuously improved and become more prominent.

\section{STRENGTHENING THE CONSTRUCTION OF TEACHERS TO GUARANTEE THE QUALITY OF INTERNATIONAL TEACHING}

Colleges should gradually establish a highly international educational condition, that is, internationalization of teaching staff. Professional teachers should receive some professional training abroad, or introduce excellent professional returnees. All of them can carry out English professional courses. Moreover, foreign teachers from different countries have different cultural background. Colleges employ a certain proportion of foreign teachers from different countries, which can not only meet daily teaching needs, but also provide opportunities for students to broaden their international and cross-cultural perspectives. To improve teachers' communication skills, colleges also deeply cooperate with industry guest teachers of industry development manager system, hire international brand hotel management personnel, conduct teaching and skill teaching evaluation according to hotel work standards, and form a 
"customer-oriented" mechanism for skill teaching quality monitoring. Colleges cooperate with the overseas international hotel management school, adopt certain modern technology means, and present these videos from the teachers or industry experts in overseas international hotel management colleges while recording these teaching videos, so as to build a "trans-time-and-space class". Colleges should break the boundaries of space and region, and truly realize the classroom effect of global resource sharing and zero distance international teaching. In cooperation with the overseas hotel management college, colleges also can use the quality standards authority for overseas higher education to assess the quality of teaching risk every year. That is to say, colleges should upload the teacher curriculum teaching plan to the supervision platform, submit the curriculum test paper to evaluate the partners, and conduct spot check on the teaching quality of teachers from time to time to ensure that the teaching content and quality of teachers are updated in time.

\section{CONCLUSION}

In a word, it is necessary to strengthen the training of international hotel management professionals under the background of tourism globalization. Intensifying the internationalization of tourism talents can not only effectively stimulate the rapid development of China's national economy, but also enhance China's comprehensive national strength to a certain extent. Based on the analysis of the current situation of the training of hotel management talents in higher vocational colleges, this paper proposes some effective measures to improve the quality of hotel management talent training in higher vocational colleges so as to speed up the development of tourism in China.

\section{REFERENCES}

[1] Yu Guihua. Route Choice of Career - Quality Education in Higher Vocational Colleges [J]. Education and Vocation, 2007 (10) (in Chinese)

[2] Zeng Ting. On the Cultivation of Higher Vocational Students' Professional Quality [J]. Education and Teaching Forum, 2015. (in Chinese)

[3] Jiang Wei. Problems and Strategies of the Internationalization Path of Higher Vocational Education in China [J]. China Higher Education Research, 2006 (05) (in Chinese) 